\title{
Yerel Halkın Cittaslow Hareketi Bağlamında Turizm Algısı: Seferihisar ve Gökçeada'da Bir Araştırma ${ }^{1}$
}

\author{
Murat Aksu* \\ Çanakkale Onsekiz Mart Üniversitesi \\ Turizm Fakültesi \\ orcid.org/0000-0003-2429-4624
}

\author{
Nedim Görman \\ Çanakkale Onsekiz Mart Üniversitesi \\ Sosyal Bilimler Enstitüsü \\ orcid.org/0000-0002-6595-0299
}

Gönderilme Tarihi

09.09.2019

Kabul Tarihi

13.09.2019

\section{$\ddot{O} z$}

Cittaslow hareketi şehirlerin kendine ait özelliklerini ve değerlerini korumayı amaçlayan bir harekettir. Cittaslow hareketi, turizmin neden olabileceği kültürel yozlaşma, doğa tahribatı ve çevre kirliliği gibi birçok olumsuz etkiye engel olmayı hedeflemektedir. Bu şekilde turizmin gelişiminde önemli rolü olan yerel halkın, turizme bakışı olumlu yönde etkilenecektir. Çalışmada Cittaslow hareketi bağlamında Seferihisar ve Gökçeada'daki yerel halkın Cittaslow hareketi bağlamında turizm algısının nasıl olduğunu belirlemek amacıyla yapılmıştır. Örneklem belirlenirken seçilme şanslarının eşit olması için basit tesadüfi örnekleme yöntemi kullanılmıştır. Bu yöntemle Haziran-Eylül 2017 tarihlerinde 251'i Gökçeada'da ve 203'ü Seferihisar'da olmak üzere toplam 454 katılımcıya ulaşılarak, kişilerle yüz yüze anket yapılmıştır. Çalışma sonucunda katılımclların sakin şehir algısına en çok etkiyi yapan sosyo-ekonomik faktörler olurken, çevresel faktörlerin etkisinin beklenenin altında olduğu görülmüş̧ür. Gökçeada ve Seferihisar halklarının Cittaslow algılar arasında belirgin bir farklllık görülmemiştir. Her iki yöre halklarının da genel olarak Cittaslow'a olumlu baktıkları sonucuna ulaşılmıştır. Cittaslow'un çevresel ve sosyokültürel etkilerinden bekâr katılımcıların daha memnun oldukları görülmüştür. Ayrıca kamu sektöründe çalışanlarm özel sektör çalışanlarma ve esnafa göre çevresel etkileri daha olumlu değerlendirdikleri sonucuna ulaşılmıştır.

Anahtar Kelimeler: Turizm, Turizm algısı, Cittaslow, Seferihisar, Gökçeada

\section{Local Communities Perception towards Tourism in the Context of Cittaslow Movement: A Research in Seferihisar and Gökçeada}

\section{Abstract}

Cittaslow is a movement that aspire to protect unique cultural properties and values. Cittaslow movement are intended, pretend to environmental pollution, ecocide caused by tourism activites and protection of local culture. In this manner, tourism perceptions of local community who play an important role in the development of tourism would be affected positively. Scope of this research is determination of local communities' perceptions on tourism in the context of Cittaslow movement in Seferihisar and Gökçeada regions. In order to have equal chance of selection, simple random sampling method was used in related research which total of 454 participants, 251 of whom were in Gökçeada and 203 of which were in Seferihisar, were interviewed in June-September 2017. Correlation between Cittaslow perceptions and socioeconomic factor of local community has detected with results of research. According to results, correlation between environmental factors and Cittaslow perceptions is lower than expected. There is no significant difference on Cittaslow perceptions of local communities Gökçeada and

\footnotetext{
${ }^{1}$ Bu çalışma Çanakkale Onsekiz Mart Üniversitesi Sosyal Bilimler Enstitüsü Turizm İşletmeciliği Anabilim Dalında Nedim GÖRMAN tarafından yapılan "Yerel Halkın Cittaslow Algısı: Seferihisar ve Gökçeada Karşılaştırması" adlı yüksek lisans tezinden üretilmiştir.

*Yazışma adresi. Email: drmurataksu@comu.edu.tr
} 
Seferihisar. Perceptions of both side are possitive about Cittaslow policies and movement. According to analysis on relation between perceptions differences and demographic varieties, unmarried have positive perceptions than marride and public employees have more positive perceptions than private sector employee.

Keywords: Tourism, Tourism perception, Cittaslow, Seferihisar, Gökçeada

\section{Giriş}

Gelişen dünyada, kentler üretimden çok tüketen ve insanların hızlı hareket edip hızlı yaşadıkları yerlere dönüşmüştür. İnsanların gidecekleri yere daha hızlı ulaşma çabası, daha hızlı yemek yemesi ve daha hızlı alışveriş yapmak istemesi, kasap, bakkal gibi küçük esnaf olarak bilinen işletmelerin sonunu getirmiş ve yerlerini alışveriş merkezlerinin almasına yol açmıştır. Yeşil alanlar, oyun parkları yerini otopark ve yollara birakmıştır. Bu durum beraberinde hava ve çevre kirliliğini, insan iletişimindeki azalmayı ve sağlıksız beslenmeyi getirmiş, insanlar mahallesindeki esnafı tanımayan, ayaküstü yemek yiyen bireylere dönüşmüştür. Bu kentlerin tamamen tüketim toplumu haline gelmesi sadece yakın çevresindeki değil dünyanın birçok yerindeki kaynakları, doğayı ve insanları tüketmesi anlamına gelmektedir. Tüketim ve hız odaklı yaşamın insana mutluluk getirmemesi Cittaslow kavramının ortaya çıkmasında rol oynamıştır. Cittaslow felsefesi, insanların teknolojiden yararlanarak yaşamdan zevk alabilecekleri hızda yaşamalarını, sosyalleşmelerini, kültürlerine ve çevrelerine sahip çıkmalarını savunmaktadır (cittaslowturkiye.org, 28.06.2019). Cittaslow hareketi ise şehirlerin kendine ait özelliklerini ve değerlerini korumayı amaçlayan bir harekettir. Ayrıca Cittaslow hareketi, turizmin neden olabileceği kültürel yozlaşma, doğal tahribatı ve çevre kirliliği gibi birçok olumsuz etkiye engel olmayı hedeflemektedir. Bu şekilde turizmin gelişiminde önemli rolü olan yerel halkın, turizme bakışı olumlu yönde etkilenecektir (Andarabi vd., 2014: 7).

Bir bölgede turizmin başarılı olması için bölgenin sahip olduğu doğal zenginlikler, kültürel ve tarihi değerler oldukça önemli faktörlerdir. Sanayileşme ve hızlı tüketim alışkanlıkları bu faktörleri olumsuz şekilde etkiler. Bu da beraberinde tatminsizliği getirebilir. Cittaslow gerçekleşmesi muhtemel olan olumsuzluklara engel olmak isteyen ve yaşamı mükemmelleştirmeye çalışan bir markadır. Cittaslow ünvanı taşıyan şehirler turizm planlaması yaparken sürdürülebilir kalkınma politikalarına uygun hareket etmelidir. Başta turistik amaçlarla tasarlanan Cittaslow, şehirlerin sürdürülebilirlik politikalarına da katkı sağlamıştır. Yerel halka önem verilmesi, hizmet kalitesinde standartlaşma, yerel halka ekonomik katkı, çevresel kaynakların korunması, gelişimin yavaş gerçekleşmesi ve turistlerin sorumluluk bilinciyle hareket etmesi sürdürülebilir turizmin en belirgin özellikleridir (Yurtseven vd., 2010: 53).

Turizmin sosyo-ekonomik, sosyo-kültürel ve çevresel etkisinin olduğu bilinmektedir. Bu etkilerin olumlu olması için sürdürülebilir turizm hareketlerinin daha da artması gerekmektedir. Sürdürülebilir turizm hareketleri açısında Cittaslow hareketi getirdiği kriterlerle turizmin olumlu etkilerini daha da artırmaktadır. Cittaslow hareketinde önemli unsur yerel halk olmaktadır. Bu da yerel halkın sosyoekonomik, sosyo-kültürel ve çevresel olarak daha bilinçli hale gelmesini sağlamaktadır. 
Cittaslow hareketine geçen yerlerde yapılan çalışmalar bunu destekler niteliktedir. Bu çalışmalardan bazıları şunlardır: Coşar, 2014; Çakıcı vd. 2014; Kazancıoğlu ve Dirsehen, 2016; Sarıbaş vd. 2016; Bucak ve Turhan, 2016; Gökaliler, 2017; Dindar ve Sert, 2018. Fakat çalışmalardan hiçbiri iki yerel halkının Cittaslow hareketine yönelik turizm algısını ölçmemiştir. Bu nedenle çalışmada Seferihisar ve Gökçeada'daki yerel halkın Cittaslow hareketi bağlamında turizm algısının nasıl olduğunu belirlemek amacıyla yapılmıştır.

\section{Cittaslow Kavramı}

Cittaslow ismi İtalyanca'da şehir anlamina gelen "citta" ve İngilizcede yavaş anlamına gelen "slow" kelimelerinin birleşmesiyle oluşmuştur. Cittaslow kavramının temelleri 1999 yılında İtalya'da Orvieto şehrinde belediye başkanlığı yapan, "Slow Food" hareketinin kurucusu Carlo Petrini öncülügünde Bra, Greve ve Positano şehirlerinin belediye başkanlarıyla birlikte atılmıştır. Başarılı birer turizm bölgesi olan bu dört şehirde fast food restoranları artmış, araç ve gürültü kirliliği fazlalaşmıştır. Kurucuların niyetleri hızlı ve hareketli hayatı sakinleştirip, yerel ve kültürel değerleri korumaktır (Knox ve Mayer 2009).

Yaşam kalitesini ve sürdürebilirliği arttırmak amacıyla ortaya atılan Cittaslow fikri günümüzde 28 ülkenin 182 şehrinde benimsenmiştir Cittaslow "yavaş, sakin şehir" anlamına gelmektedir. Bu kavram, Latinlerin "Festina Lente" dediği yavaşça acele etmeyi ve günün şartlarına uyarak geçmişten kopmamayı hedeflemektedir. Cittaslowlar, nüfusu 50.000'in altında olan, yöresel kültürünü, yemeklerini ve tarihi değerlerini muhafaza eden uluslararası şehirler topluluğudur. Bu topluluğa dâhil olmak isteyen şehirlerin güçlü ve zayıf yönlerin iyi analiz etmesi gerekmektedir (www.cittaslowturkiye.org, 28.06.2019).

Sakin şehir yaklaşımı, Latincede "yavaş acele" anlamına gelen "festina lente" deyiminin şehir yaşamına uyarlanması anlamına gelebilmektedir. Bu durum günün imkânlarından faydalanarak geçmişin dokusuna sahip çıkmayı amaçlamaktadır. Cittaslow oluşumuna katılmak isteyen şehirler, kriterler ve standartlar dâhilinde değerlendirildikten sonra hak kazandıkları takdirde bir sertifika ile kabul edilirler. Oluşumun parçası olan şehirler, üzerinde Cittaslow'un simgesi olan salyangozlu bayrakları dalgalandırabilirler. Oluşuma dâhil olan şehirlerde turistik olarak büyük hareketlilikler yaşandığı gözlemlenmiştir (Sezgin ve Ünüvar, 2011: 133).

Cittaslow kavramının beraberinde getirdiği sürdürülebilir turizm türü, kültürü ve doğal çevreyi koruyarak bir toplumun gelişmesi yolunda büyük rol oynamaktadır (Butler, 1990: 201). Cittaslow yerel kaynakların ve tarihi dokunun korunmasını ve sürdürülebilir kalkınmayı teşvik etmektedir. Küçük kentlerin nüfuslarındaki düşüşler; yerel ekonomik canlanma ve sosyal faaliyetlerdeki gelişmeler sayesinde önlenebilmektedir. Cittaslow, insani değerlere önem veren bir hareket olarak karşımıza çıkmaktadır (Tayfun ve Acuner, 2014: 47).

Sakin Şehir kavramı sakin yaşamın yanı sıra fiziksel çevreyi, yerel mutfağı ve kültürü korumayı hedefler. Daha sağlıklı çevreler oluşturmak ve bireylerin boş 
vakitlerini daha iyi değerlendirmelerini sağlamak için teknolojiden faydalanılmasını da desteklemektedir. Bu hareketin amacı; sürdürülebilir ve sağlıklı çevre, sağlıklı ve iyi gıda sağlayarak toplum gelişimine fayda sağlamaktır. Daha sonra bu özellikler maddeler haline getirilmiştir. Liste yemekten zevk almayı ve eşsiz gıdaları desteklemektedir. Maddeler doğrultusunda ziyaretçilere yerel lezzetleri deneyebilme imkânı sağlanmaktadır. Yörenin ayırt edici özelliklerinin korunması son derece önemlidir. Şehir planlamasını da kapsayan bu listeye göre; aday kentler, bölgenin özelliklerini taşıyan el sanatlarını da desteklemelidir. Bunlarla beraber listede; 1şıklı panoların kaldırılması, araba alarmlarının yasaklanması, ses ve görüntü kirliliğinin azaltılması, yeşillendirme çalışmaları, yaya ve bisiklet yollarının arttırılması gibi çevre düzenlemeleri de yer almaktadır (Knox ve Mayer, 2009: 11).

Cittaslow Birliği nüfusu 50.000 altında olan şehirlerin üye olabildiği uluslararası bir birliktir. Bu birliğe üye olmak, birlik tarafından belirlenen kriterleri yerine getirmek amacıyla proje geliştirmek ve uygulamayı gerektirmektedir. Bu kriterler çerçevesinde puanlandırılan şehirler 50 ve üzerinde puan aldıkları takdirde üyelik hakkı kazanmaktadır. 1999 yılında belirlenen, daha sonrasında birliğin Avrupa dışına çıkıp dünyaya yayılmasıyla evrenselleşen kriterler ilk aşamada bir senelik deneme süresine tabi tutulmaktadır. Bu kriterler 7 başlık altında toplanmaktadır: Çevre politikaları 12 kriterden, altyapı politikaları 9 kriterden, kentsel yaşam kalitesi politikaları 17 kriterden, tarımsal, turistik, esnaf ve sanatkârlara yönelik politikalar 10 kriterden, misafirperverlik, farkındalık ve eğitim için politikalar 10 kriterden, sosyal uyum politikaları 11 kriterden ve ortaklık politikaları 3 maddeden oluşmaktadır (www.cittaslowturkiye.org, 28.06.2019).

Türkiye'deki sakin şehirler ülkenin her yanında görülebilmektedir. Türkiye'nin doğusunda, batısında, kuzeyinde ve güneyinde sakin şehir organizasyonuna katılmış kentlerimiz bulunmaktadır. Adaylık sürecinde olan veya aday olmayı düşünen, başvuruda bulunan şehirlerimiz mevcuttur. Şu an için Türkiye'de; Seferihisar, Akyaka, Gökçeada, Halfeti, Taraklı, Vize, Yalvaç, Yenipazar, Perşembe, Şavşat, Uzundere, Eğirdir, Gerze, Göynük, Mudurnu, Köyceğiz ve Ahlat olmak üzere 17 tane sakin şehir vardır (www.cittaslowturkiye.org, 24.06.2019).

\section{Alan Yazında Cittaslow Araştırmaları}

Coşar (2014), Seferihisar halkı, işletme sahipleri, yerli turistler ve belediye başkanı ile görüşmeler yapmıştır. Görüşmeler sonucunda, sakin şehir olduktan sonra çevreye ve altyapıya önem verildiği, halkın üretime teşvik edildiği, sosyal etkinliklerin arttığı, yeni işletmelerin açıldığ 1 ve istihdamın arttığ bu sebeplerden dolayı da yaşam kalitesinde artış olduğu sonucuna ulaşmıştır. Araştırmada, ilçenin tanınması ile gelen nüfus artışı, kalabalık, gürültü, trafik, fazla yapılaşma, emlak fiyatlarında artış ve hayat pahalılığı gibi olumsuz sonuçlar da ortaya çıkmıştır.

Çakıcı vd. (2014), Seferihisar halkının Yavaş Şehir algısının yaşam doyumlarına etkisini incelenmek istemiştir. Çalışmada kullanılan anketler sonucunda, Seferihisar halkının turizmi olumlu yönde algıladıkları ve Yavaş Şehir olduktan sonra yerel halkın yaşam doyumunda olumlu yönde gelişme olduğu görülmüştür. Çalışmaya göre Yavaş 
Şehir hareketi, istihdam, kamu hizmetleri, yaşam standartları ve yerel ekonomiye olumlu etki etmektedir.

Kazancıŏlu ve Dirsehan (2016), yaptıkları çalışmada Seferihisar belediye başkanıyla görüşme yaparak sakin şehirlerin ortaya çıkardığ 1 girişimler ve girişimciler hakkında bilgi edinmeyi amaçlamışlardır. Bu çalışma sakin şehirleri sosyal inovasyon yönünden inceleyen ilk çalışmadır. Görüşmeyi desteklemek için bölgede gözlem çalışmaları da yapılmıştır. Çalışmada Seferihisar Belediye Başkanı bir sosyal girişimci olarak görülmüştür.

Sarıbaş vd. (2016), yaptıkları çalışmada sakin şehirlerde yaşayan "Z Kuşağı" olarak adlandırılan gençlerin sürdürülebilir çevre algılarını ortaya çıkarmayı amaçlamışlardır. Çalışmada yöre gençlerinin sürdürülebilir doğa, çevre koruması ve planlama gibi kavramlar hakkındaki farkındalıkları ölçülmeye çalışılmıştır. Araştırmada belediyenin ve bölgede bulunan bazı sivil toplum örgütlerinin gençleri bilinçlendirmeye çalıştığı görülmüştür. Yeni neslin bilinçlenmesi, eğitilmesi ve kültürel mirasa sahip çıkması için etkinlik ve festivallere onların katılımını sağlamanın önemli olduğu vurgulanmıştır.

Bucak ve Turan (2016), yaptıkları çalışmada Yavaş Yemek akımından sonra Gökçeada'da meydana gelen değişiklikleri tespit edilmeye çalışılmıştır. Çalışmada konaklama ve yiyecek içecek işletmeleri, turizm çeşitliliği, ulaşım, tanıtım ve ziyaretçi sayıları göz önünde bulundurulmuştur. Gökçeada halkının Yavaş Yemek kavramı hakkında yeterince bilgili olmadığı tespit edilmiştir. Yapılan görüşmelerin sonucunda 2006-2015 yılları arasında işletme sayılarında artış olduğu, pansiyon ve butik otellerin arttığ1 ve yöresel yemek yapan işletmelerin açıldığı görülmüşsür.

Gökaliler (2017), yaptığ1 çalışmaya göre; Seferihisar, konum ve kültürel yapısı ile sakin şehir ünvanını başarıyla taşımaktadır. Yerel yemekler ve yerel üretimin desteklenmesinin yanı sıra belediye de halkı bilinçlendirmeye yönelik çalışmalar yapmaktadır. Seferihisar'da Cittaslow felsefesinin getirdiği huzur ve sakinliğin başarıya ulaştığı görülmektedir. Seferihisar'da görülen, kendine özgü bir yaşam tarzı sunması, yerel halkın ihtiyaçlarını karşılaması, yerel halkın yaşam alanına yönelik çabalar şehri rakiplerinden farklı kılmaktadır. Yerel halkın da durumu benimsemesi Seferihisar'ın bu anlamda markalaştığını göstermektedir. Araştırmada yerel halkın, kendi yaşam tarzlarını gelen yerli ziyaretçilere de yansıttıkları görülmüştür. Seferihisar sadece turistik bir yer değil yaşanılan, doğal bir yer olarak da görülmektedir. Cittaslow hareketi, Seferihisar'ın rakiplerinden farklılaşmasına ve yerel halkın yaşam kalitesinde artışa neden olmuştur.

Dündar ve Sert (2018), çalışmalarında Seferihisar'da yaşayan yerel halkın sakin şehir olgusuna ilişkin algısı incelenmiştir. Çalışmada nitel araştırma tekniklerinden görüşme tekniği kullanılmıştır. Yerel halk, genel olarak, şehrin sakin şehir olmasından memnun olduklarını, sakin şehir olduktan sonra şehirde ekonominin canlandığını, ziyaret artışı ile birlikte turizmin geliştiğini, şehrin çevresel ve sosyo-kültürel olarak geliştiğini ve şehrin tanınırlığının arttığını dile getirmişlerdir. Bununla birlikte, yerel halk, sakin şehir ile birlikte şehirde trafik sıkışıklığı, aşırı ve çarpık kentleşme, gürültü, 
bölgesel enflasyon, kalabalıklaşma ve çevre kirliliği sorunlarının ortaya çıktığını belirtmişlerdir. Yerel halkın daha çok sakin şehrin ekonomik sonuçlarına odaklanarak memnuniyetlerini dile getirdikleri tespit edilmiştir.

\section{Yöntem}

\subsection{Araștırmanın Amacı ve Önemi}

Sakin (Yavaş) Şehirler (Cittaslow), hızlı yaşam alışkanlıklarının neden olduğu yok olma ve bozulmalara karşı, bir koruma şeklinde meydana gelmiştir. Tarihi, kültürel ve doğal mirasa saygilı; küçük fakat hayat kalitesi fazla olan kentler, Cittaslow (Sakin Şehir) hareketinin temel hedefi olma niteliğini taşımaktadırlar. "Sakin Şehir Hareketi", İtalya'da başlamış 10 yıl içerisinde farklı bir şehir ve yaşam modeli meydana getirmiştir. En önemli amacı yerel toplumun ve ziyaretçilerinin yaşam kalitesini arttırmak olan Cittaslow hareketi, kısa bir süre içerisinde uluslararası bir ağ halini almıştır. Yapılan bu araştırmada, turizm kavramı ve genel hatları, güncel bir konu olan yerel halkın Cittaslow algısı üzerinde durularak Gökçeada ve Seferihisar karşılaştırması yapılmıştır. Çalışmanın amacı, hızla gelişmekte olan turizm sektöründeki çalışmalara ek olarak Cittaslow algısı kavramına açıklık getirmek, iki merkezi karşılaştırarak nicel veriler ile yerel halkın algı oranını belirlemektir. Çalışma iki merkezin karşılaştırılması bakımından özgündür. Bu açıdan literatüre katkı sağlayacaktır.

$\mathrm{Bu}$ araştırma, Cittaslow turizm algısı konusunda literatüre zenginlik kazandırmanın yanı sıra Gökçeada ve Seferihisar kentlerinde yaşayan kişilerin Cittaslow ile ilgili algılarının çeşitli değişkenler açısından ortaya koyması bakımından büyük önem taşımaktadır.

\section{Hipotezler}

Konu ile ilgili alan yazının ışığında şu hipotezler belirlenmiştir:

$\mathrm{H}_{1 a}$ : İkamet edilen yer açısından Cittaslow hareketi bağlamında turizmin sosyoekonomik etkileri istatistiki olarak anlamlı farklılık göstermektedir.

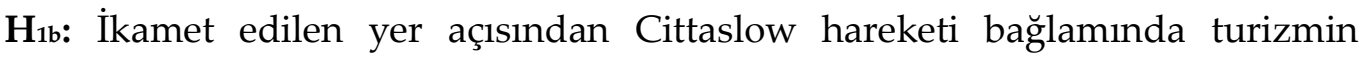
çevresel etkileri istatistiki olarak anlamlı farklılık göstermektedir.

$H_{1 c:}$ İkamet edilen yer açısından Cittaslow hareketi bağlamında turizmin sosyokültürel etkileri istatistiki olarak anlamlı farklılık göstermektedir.

$\mathbf{H}_{2}$ : İkamet edilen yer açısından Cittaslow imajı istatistiki olarak anlamlı farklılık göstermektedir.

$\mathbf{H}_{3 a}$ : Cinsiyet açısından Cittaslow hareketi bağlamında turizmin sosyoekonomik etkileri istatistiki olarak anlamlı farklılık göstermektedir.

$\mathbf{H}_{3 \mathrm{~b}}$ : Cinsiyet açısından Cittaslow hareketi bağlamında turizmin çevresel etkileri istatistiki olarak anlamlı farklılık göstermektedir.

H3c: Cinsiyet açısından Cittaslow hareketi bağlamında turizmin sosyo-kültürel etkileri istatistiki olarak anlamlı farklılık göstermektedir. 
$\mathbf{H}_{4}$ : Cinsiyet açısından Cittaslow imajı istatistiki olarak anlamlı farklılık göstermektedir.

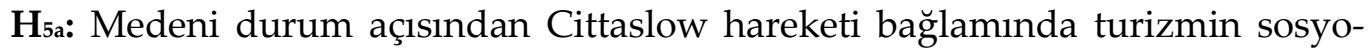
ekonomik etkileri istatistiki olarak anlamlı farklılık göstermektedir.

$\mathbf{H}_{5 b}$ : Medeni durum açısından Cittaslow hareketi bağlamında turizmin çevresel etkileri istatistiki olarak anlamlı farklılık göstermektedir.

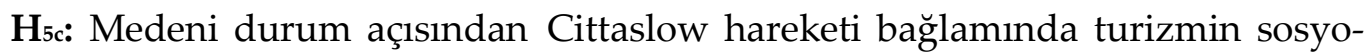
kültürel etkileri istatistiki olarak anlamlı farklılık göstermektedir.

H6: Medeni durum açısından Cittaslow imajı istatistiki olarak anlamlı farklılık göstermektedir.

Ha: $_{7}$ Yaş açısından Cittaslow hareketi bağlamında turizmin sosyo-ekonomik etkileri istatistiki olarak anlamlı farklılık göstermektedir.

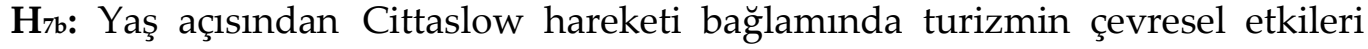
istatistiki olarak anlamlı farklılık göstermektedir.

H7c: Yaş açısından Cittaslow hareketi bağlamında turizmin sosyo-kültürel etkileri istatistiki olarak anlamlı farklılık göstermektedir.

$H_{8}$ : Yaş açısından Cittaslow imajı istatistiki olarak anlamlı farklılık göstermektedir.

Ha: Meslek açısından Cittaslow hareketi bağlamında turizmin sosyo-ekonomik etkileri istatistiki olarak anlamlı farklılık göstermektedir.

$\mathbf{H}_{9 b}$ : Meslek açısından Cittaslow hareketi bağlamında turizmin çevresel etkileri istatistiki olarak anlamlı farklılık göstermektedir.

H9c: Meslek açısından Cittaslow hareketi bağlamında turizmin sosyo-kültürel etkileri istatistiki olarak anlamlı farklılık göstermektedir.

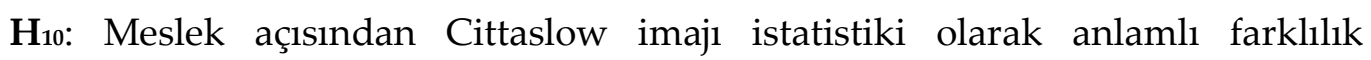
göstermektedir.

H11a: Gelir kaynağı açısından Cittaslow hareketi bağlamında turizmin sosyoekonomik etkileri istatistiki olarak anlamlı farklılık göstermektedir.

H11b: Gelir kaynağı açısından Cittaslow hareketi bağlamında turizmin çevresel etkileri istatistiki olarak anlamlı farklılık göstermektedir.

H11c: Gelir kaynağ1 açısından Cittaslow hareketi bağlamında turizmin sosyokültürel etkileri istatistiki olarak anlamlı farklılık göstermektedir.

H12: Gelir kaynağı açısından Cittaslow imajı istatistiki olarak anlamlı farklılık göstermektedir.

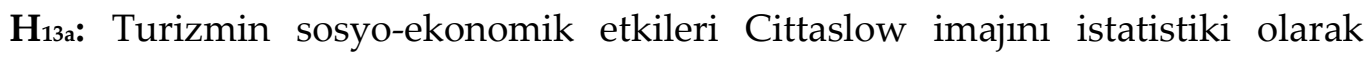
anlamlı ve pozitif yönde etkilemektedir. 
$\mathbf{H}_{13 b:}$ Turizmin çevresel etkileri Cittaslow imajını istatistiki olarak anlamlı ve pozitif yönde etkilemektedir.

H1зс: Turizmin sosyo-kültürel etkileri Cittaslow imajını istatistiki olarak anlamlı ve pozitif yönde etkilemektedir.

H14: Yaş değişkeni Cittaslow imajını istatistiki olarak anlamlı ve negatif yönde etkilemektedir.

H15: Bölgede yaşam süresi Cittaslow imajını istatistiki olarak anlamlı ve negatif yönde etkilemektedir.

\subsection{Evren ve Örneklem}

Araştırma evreni olarak Türkiye'deki iki Cittaslow şehri olan Gökçeada ve Seferihisar ilçeleri belirlenmiştir. Bu bağlamada araştırmanın evrenini Türkiye İstatistik Kurumu (TUIK) Adrese Dayalı Kayıt Sistemi 2018 yılı verilerine göre Çanakkale'nin Gökçeada ilçesinde yaşayan 9.783 kişi ile İzmir'in Seferihisar ilçesinde yaşayan 43.546 kişi olmak üzere toplam 53.329 bireyden oluşturmaktadır.

Araştırmada zaman ve maliyet kısıtlarından dolayı örnekleme yöntemine gidilmiştir. Örneklem belirlenirken seçilme şanslarının eşit olması için basit tesadüfi örnekleme yöntemi kullanılmıştır. Bu yöntemle Haziran-Eylül 2017 tarihlerinde 251'i Gökçeada'da ve 203'ü Seferihisar'da olmak üzere toplam 454 katılımcıya ulaşılarak, kişilerle yüz yüze anket yapılmıştır. Güvenirlik açısından 100.000 kişinin üzerindeki evrenlerde 384 örneklemin yeterli olduğu ifade edilmektedir. Bu yüzden örneklemin \%95 güvenirlik düzeyinde evreni temsil etme gücüne sahip olduğu ifade edilebilir.

\subsection{Veri Toplama Aracı ve Teknikleri}

Araştırmada veri toplama aracı olarak anket yöntemi kullanılmıştır. Düzenlenen anket formu iki bölümden oluşmaktadır. Birinci bölümde katılımcıların demografik özellikleri belirlemeye yönelik cinsiyet yaş gibi ifadeler yer almaktadır. İkinci kısımda ise daha önce Andarabi, Altunöz ve Hassan (2014)'ün araştırmalarında kullandıkları ölçek kullanılmıştır. Andarabi, Altunöz ve Hassan (2014)'ın çalışmasında yerel halkın turizm etkilerine yönelik algı ölçeği 0,892 düzeyinde Cittaslow marka imajı ölçeği ise 0,926 düzeyinde güvenilir bulunmuştur. Ölçekler 5'li likert ölçeğine göre düzenlenmiştir (1=hiç katılmıyorum, 2=katılmıyorum, 3=kararsızım, 4=katıliyorum, 5=tamamen katıliyorum).

\subsection{Verilerin Analizi}

Araştırmada elde edilen verilerin analizi için SPSS 21 (Statistical Package for the Social Science) istatistik paket programından faydalanılmıştır. Araştırmaya katılan kişilere yönelik tanımlayıcı bilgiler yüzde ve frekans analizi yöntemi kullanılarak analiz edilmiştir. Ankete verilen cevaplara ilişkin dağılımlar, ölçeğe ilişkin güvenilirlik analizleri, aritmetik ortalamalar ve standart sapmalar verilmiştir. Bununla birlikte faktör analizi, karşılaştırma analizleri, korelasyon ve regresyon analizleri yapılmıştır. 
Verilerin analizine geçilmeden önce verilerin normal dağılıp dağılmadığına bakılmıştır. Buna göre çarpıklık ve basıklık değerleri incelenmiştir. West ve diğerleri (1995)'ne göre çarpıklık değeri için \pm 2 ve basıklık değeri için \pm 7 değerlerinin üstüne çıkıldığında normal dağılımdan çıkıldığını bildirmektedir. Buna göre gözlenen verilerin çarpıklık düzeyinin \pm 2 ve basıklık düzeyinin \pm 7 değeri arasında olduğu için normal dağılım gösterdiği kabul edilmiştir.

\section{Bulgular}

Bu bölümde araştırma hipotezlerinin test edilme süreci açıklanmıştır. İlk olarak araştırma katılımcılarının tanımlayıcı özellikleri incelenmiştir. Daha sonra ölçeklere ilişkin faktör analizleri, güvenirlik analizleri, fark testleri (bağımsız örneklem t testi, tek yönlü varyans analizi), korelasyon ve regresyon analizleri ile bulguları değerlendirilmiştir.

\subsection{Katılımcılarının Tanımlayıcı Özelliklerine Yönelik Bulgular}

Tablo 1, katılımcıların demografik özelliklerini göstermektedir.

Tablo 1. Katılımcıların Demografik Özellikleri

\begin{tabular}{|c|c|c|c|c|c|c|c|}
\hline \multicolumn{2}{|c|}{ Değişkenler } & \multirow{2}{*}{$\begin{array}{c}\text { Frekans } \\
198\end{array}$} & \multirow{2}{*}{$\begin{array}{c}\text { Yüzde } \\
43,6 \\
\end{array}$} & \multicolumn{2}{|c|}{ Değişkenler } & \multirow{2}{*}{\begin{tabular}{|c|} 
Frekans \\
139
\end{tabular}} & \multirow{2}{*}{\begin{tabular}{|c|} 
Yüzde \\
30,6
\end{tabular}} \\
\hline \multirow[b]{2}{*}{ Cinsiyet } & Kadın & & & \multirow{6}{*}{ Meslek } & Esnaf & & \\
\hline & Erkek & 256 & 56,4 & & $\begin{array}{l}\text { Kamu } \\
\text { Çalışanı }\end{array}$ & 49 & 10,8 \\
\hline \multirow{2}{*}{$\begin{array}{l}\text { Medeni } \\
\text { Durum }\end{array}$} & Evli & 225 & 49,6 & & $\begin{array}{l}\text { Özel Sektör } \\
\text { Calıșanı }\end{array}$ & 129 & 28,4 \\
\hline & Bekâr & 229 & 50,4 & & Ev Hanımı & 30 & 6,6 \\
\hline \multirow{5}{*}{ Yaş } & 18-24 Yaş & 116 & 25,6 & & Emekli & 31 & 6,8 \\
\hline & 25-34 Yaş & 173 & 38,1 & & Öğrenci & 76 & 16,7 \\
\hline & 35-44 Yaş & 88 & 19,4 & \multirow{3}{*}{\begin{tabular}{|l} 
Çalıştığınız \\
Sektör
\end{tabular}} & $\begin{array}{l}\text { Turizmle } \\
\text { Ilgili }\end{array}$ & 72 & 15,9 \\
\hline & 45-54 Yaş & 47 & 10,4 & & \begin{tabular}{|l} 
Turizmle \\
İlgili Değil
\end{tabular} & 348 & 76,7 \\
\hline & $\begin{array}{l}55 \text { Yaş ve } \\
\text { Üstü }\end{array}$ & 30 & 6,6 & & \begin{tabular}{|l|} 
Gelirimin \\
Bir Kısmı \\
Turizmden \\
\end{tabular} & 34 & 7,5 \\
\hline \multirow{7}{*}{$\begin{array}{c}\text { Aylık } \\
\text { Gelir } \\
\text { (TL) }\end{array}$} & 1000 ve alt1 & 96 & 21,1 & \multirow{2}{*}{$\begin{array}{c}\text { İkamet } \\
\text { Edilen Yer }\end{array}$} & Gökçeada & 251 & 55,3 \\
\hline & $1000-1500$ & 35 & 7,7 & & Seferihisar & 203 & 44,7 \\
\hline & $1501-2000$ & 92 & 20,3 & \multirow{6}{*}{$\begin{array}{l}\text { Kaç Yıldır } \\
\text { Yaşanıyor }\end{array}$} & $1-5 Y_{11}$ & 130 & 28,6 \\
\hline & 2001-2500 & 70 & 15,4 & & 6-10 Y11 & 122 & 26,9 \\
\hline & \begin{tabular}{|l|}
$2501-3000$ \\
\end{tabular} & 67 & 14,8 & & 11-15 $\mathrm{Y}_{11}$ & 58 & 12,8 \\
\hline & $\begin{array}{l}3001-4000 \\
\text { TL }\end{array}$ & 59 & 13,0 & & $16-20 Y_{11}$ & 66 & 14,5 \\
\hline & \begin{tabular}{|l|}
4000 ve \\
üstü
\end{tabular} & 35 & 7,7 & & 21-25 Y1l & 32 & 7,0 \\
\hline \multicolumn{2}{|c|}{ Toplam } & 454 & 100,0 & & $25 Y_{11}$ Üstü & 46 & 10,1 \\
\hline
\end{tabular}


Araştırmaya katılanların yaklaşık olarak \%56'sı erkeklerden \%44'ü kadınlardan oluşmaktadır. Katılımcılar arasında evli ve bekârların oranı yaklaşık olarak birbirine eşittir. Katılımcıların \%38'i 25-34 yaş arasındayken yaklaşık \% 26's1 18-24 yaş arasındadır. Katılımcıların yaklaşık \%21'nin aylık geliri 1000 TL'nin altında ve yaklaşık \%20'sinin aylık geliri 1501-2000 TL arasındadır. Katılımcların yaklaşık \% 31'i esnaflardan meydana gelirken \% 28'i özel sektör çalışanlarından oluşmaktadır. Katılımcıların büyük çoğunluğunun çalıştığ1 sektör turizm ile ilişkili değildir. Araştırmaya katılanların \%55'i Gökçeada'da, kalan \%45'i Seferihisar'da ikamet etmektedir. Bu kişilerden yaklaşık \%29'u araştırmaya katıldıkları yerlerde 1-5 yıldan beri yaşarken, \%27'si 6 ila 10 yıldan beri yaşamaktadır.

\subsection{Açıklayıcı ve Doğrulayıcı Analizler}

Hipotezlerin test edilmesinden önce ölçeklerin geçerliliğine yönelik açıklayıcı faktör analizi yapılmıştır. Buna göre öncelikle turizmin etkileri ölçeğinin KMO ve Barlett küresellik testi değerlerine bakılmıştır. KMO ve Barlett küresellik testi değerleri istatistiki olarak anlamlı bulunması durumunda verilerin faktör analizi için uygun olduğu kabul edilmektedir. KMO değerleri 0,5 ve 1 arası değerler kabul edilebilir olarak değerlendirilebilir. Turizmin etkileri ölçeği için KMO değeri 0,884 olarak bulunmuştur. Barlett küresellik testi sonucu 6841,5 olarak 0,001 düzeyinde anlamlı bulunmuştur. Bu sonuçlara göre verilerin faktör analizi için yeterli büyüklükte ve uygun olduğu söylenebilir.

Yapılan ilk faktör analizi sonuçlarına göre ortak varyans değerleri 0,5 altında olan üç ifade (ifade8, ifade9, ifade18) ölçekten çıkartılmıştır. Faktör yükü 0,5'in altında olan iki ifade (ifade17, ifade19) ölçekten çıkartılmıştır. Kalan 21 ifade ile yapılan turizmin etkileri ölçeğine ilişkin faktör analizi sonuçları Tablo 2'de görülmektedir. Tabloya göre turizmin etkileri ölçeği çevresel etki, sosyo-ekonomik etki ve sosyokültürel etki olmak üzere 3 boyuta ayrılmıştır. Faktör analizi sonucuna göre faktörler toplam varyansın \%68'ini açıklamaktadır. 
Tablo 2. Turizmin Etkilerine Yönelik Faktör Analizi Sonuçları

\begin{tabular}{|c|c|c|c|c|}
\hline No & & 1 & 2 & 3 \\
\hline \multicolumn{2}{|r|}{ ÇEVRESEL ETKİ $®(\bar{x}=2,57 ;$ s.s. $=0,985)$} & & & \\
\hline 21 & $\begin{array}{l}\text { Parklar, sahiller ve piknik yerlerinin kirliliğine sebep } \\
\text { olmaktadır. }\end{array}$ & ,906 & & \\
\hline 23 & Bölgede ses kirliliğine neden olmaktadır. & ,892 & & \\
\hline 20 & Çevre ve doğanın kirlenmesine neden olmaktadır. & ,891 & & \\
\hline 24 & Kentsel dokunun bozulmasına sebep olmaktadır & 859 & & \\
\hline 22 & Bölgede trafik sıkışıklığına sebep olmaktadır. & 837 & & \\
\hline 25 & $\begin{array}{l}\text { Bölgede çevreye zararlı ticari ve sanayi faaliyetlerine neden } \\
\text { olmaktadır. }\end{array}$ & ,759 & & \\
\hline 3 & Ticari ahlâkın bozulmasına yol açmaktadır. & ,756 & & \\
\hline 7 & Aile yapısında manevi değerlere verilen önemi azaltmaktadır & ,734 & & \\
\hline 6 & Gelenek ve göreneklerin bozulmasına sebep olmaktadır. & ,729 & & \\
\hline \multicolumn{2}{|r|}{ SOSYO-EKONOMIK ETKİ $(\overline{\mathrm{x}}=3,92 ;$ s.s.=0,672) } & & & \\
\hline 13 & Halkın yaşam kalitesinin yükselmesine katkı sağlamaktadır. & & 800 & \\
\hline 12 & Önemli bir gelir kaynağıdır. & & 800 & \\
\hline 10 & Yeni iş sahaları ve istihdam sağlamaktadır. & & ,779 & \\
\hline 11 & Kadınlara ekonomik destek sağlamaktadır. & & ,770 & \\
\hline 15 & Bölgede alt yapı standartlarının yükselmesine sebep olmaktadır. & & ,700 & \\
\hline 16 & $\begin{array}{l}\text { Yerel halkın bölgeye daha fazla yatırım yapmasına sebep } \\
\text { olmaktadır. }\end{array}$ & & 664 & \\
\hline 14 & Bölgenin tanıtımına katkı sağlamaktadır. & & 640 & \\
\hline \multicolumn{2}{|r|}{ SOSYO-KÜLTÜREL ETKİ ${ }^{\circledR}(\overline{\mathrm{x}}=3,19 ;$ s.s.=0,985) } & & & \\
\hline 1 & $\begin{array}{l}\text { Yöredeki geleneksel yeme-içme alışkanlıklarını } \\
\text { değiştirmektedir. }\end{array}$ & & & ,875 \\
\hline 2 & $\begin{array}{l}\text { Restoranlarda yöresel yemekler yerine, turistlerin damak tadına } \\
\text { hitap eden yiyecek ve içecekler sunulmaktadır. }\end{array}$ & & & ,852 \\
\hline 26 & Sigara kullanımını artırmaktadır. & & & 646 \\
\hline 5 & $\begin{array}{l}\text { Yöre halkının kendi öz dilinden uzaklaşmasına sebep } \\
\text { olmaktadır. }\end{array}$ & & & ,620 \\
\hline 4 & Alkol kullanımını artırmaktadır. & & & ,605 \\
\hline \multicolumn{2}{|r|}{ Faktör Eigen Değerleri } & 6,969 & 4,050 & 3,344 \\
\hline \multicolumn{2}{|r|}{ Faktörlere Ait Açıklanan Varyans Değeri (\%) } & 33,185 & 19,288 & 15,928 \\
\hline \multicolumn{2}{|r|}{ Toplam Açıklanan Varyans (\%) } & \multicolumn{3}{|c|}{68,401} \\
\hline \multicolumn{2}{|r|}{ Kaiser-Meyer-Olkin Örnekleme Ölçüm Yeterliliği } & \multicolumn{3}{|c|}{, 884} \\
\hline & Bartlett Küresellik Test Değeri & & 1,501 sig. & \\
\hline
\end{tabular}

*Ölçekteki ifadeler ters kodlanmıştır.

Ölçekteki boyutlardan çevresel etki boyutu varyansın \%33'ünü, sosyoekonomik etki boyutu varyansın \%19'unu ve sosyo-kültürel etki boyutu varyansın \%15'ini açıklamaktadır. Çevresel etki ve sosyo-kültürel etki boyutundaki ifadelerini tamamı ters kodlanmıştır. Boyutların ortalamalarına bakıldığında sosyal ekonomik etki $(\bar{x}=3,92)$ en yüksek katılımı gösteren boyuttur. Sosyo-kültürel etki $(\overline{x=3,19)}$ ise ortalamanın üzerinde bir katılım göstermektedir. Çevresel etki boyutunda $(\bar{x}=2,57)$ 
katılım düzeyinin ortalamanın altında olduğu gözlenmektedir. Buna göre turizmin Cittaslow şehirlerinde ikamet eden yerel halka ekonomik açıdan katkılarının olduğu ve Cittaslow anlayışının şehirlerin kültürel yapılarının korunmasında etkili olduğu söylenebilir. Ancak turizm ile birlikte bu şehirlerde yerel halk tarafından negatif çevresel etkilerin olduğu gözlenmektedir.

Cittaslow imajı ölçeğine yönelik olarak faktör analizi öncesinde KMO ve Barlett küresellik testi değerlerine bakılmıştır. Buna göre $\mathrm{KMO}$ değeri 0,813 ve Barlett küresellik testi değeri 1203,5 olarak $(p<0,001)$ anlamlı bulunmuştur. Bu açıdan verilerin faktör analizi için yeterli büyüklükte ve uygun olduğu söylenebilir.

Tablo 3. Cittaslow İmajına Yönelik Faktör Analizi Sonuçları

\begin{tabular}{|c|c|c|c|c|}
\hline No & CITTASLOW İMAJI ( $\bar{x}=4,33 ;$ s.s. $=0,781)$ & $\begin{array}{l}\text { Faktör } \\
\text { Yükü }\end{array}$ & $\begin{array}{l}\text { Açıklanan } \\
\text { Varyans }\end{array}$ & $\begin{array}{l}\text { Eigen } \\
\text { Değeri }\end{array}$ \\
\hline 28 & Yörenin kalkınma ve gelişmesi için iyi bir modeldir. & ,926 & \multirow{4}{*}{$76,88 \%$} & \multirow{4}{*}{3,075} \\
\hline 29 & $\begin{array}{l}\text { Yerel halkın yaşam kalitesinin yükseltilmesi için iyi } \\
\text { bir modeldir. }\end{array}$ & ,906 & & \\
\hline 30 & Yaşadığım şehrin Cittaslow olmasından memnunum. & 871 & & \\
\hline 27 & Turist sayısının artışında etkili bir markadır. & ,799 & & \\
\hline & KMO Örnekleme Ölçüm Yeterliliği & \multicolumn{3}{|c|}{813} \\
\hline & Bartlett Küresellik Testi Chi-Square & \multicolumn{3}{|c|}{1203,561} \\
\hline & Anlamlılık Düzeyi & \multicolumn{3}{|c|}{,000 } \\
\hline
\end{tabular}

Cittaslow imajı ölçeğine yönelik olarak yapılan faktör analizi sonucunda 4 ifadenin bulunduğu ölçek tek boyutlu olarak ortaya çıkmıştır. Tablo 3'e göre tek faktör toplam varyansın \%77'sini açıklamaktadır. Katılımcıların Cittaslow imajı ölçeğine katılım düzeyi $(\bar{x}=4,33)$ ortalamanın oldukça üzerinde bulunmuştur. Buna göre katılımcıların Cittaslow'u pozitif algıladıkları ve Cittaslow'dan memnun oldukları söylenebilir. Yapılan faktör analizleri sonucunda ölçeklerin geçerli oldukları söylenebilir.

Turizmin etkileri ölçeğine ve Cittaslow imajı ölçeğine yönelik olarak yapılan güvenilir sonuçları Tablo 4'te verilmektedir. Güvenirlik analizi geliştirilen ölçme aracının (ölçeğin) ifadelerin kendi aralarında tutarlılık gösterip göstermedim test etmek amacıyla kullanılmaktadır. Güvenirlik analizi ifadelerin birbirleri arasındaki ilişkinin ölçülmesi ile ortaya çıkmaktadır. Güvenirlik katsayısı 0 ile 1 arasında değer almakta ve bu değer 1'e yaklaştıkça güvenirlik artmaktadır. Genellikle 0,7'nin üzerindeki değerler güvenilir kabul edilmektedir. 
Tablo 4. Ölçeklerin Güvenirlik Analizi Sonuçları

\begin{tabular}{|l|c|c|}
\hline \multicolumn{1}{|c|}{ Ölçek } & Iffade Sayısı & $\begin{array}{c}\text { Cronbach Alfa } \\
\text { Katsayısı }(\boldsymbol{\alpha})\end{array}$ \\
\hline Çevresel Etki & 9 & 0,944 \\
\hline Sosyo-Ekonomik Etki & 7 & 0,864 \\
\hline Sosyo-Kültürel Etki & 5 & 0,744 \\
\hline ETKI ÖLÇEĞ $\dot{I}-$ GENEL & 21 & 0,902 \\
\hline CITTASLOW IMAJI & 4 & 0,898 \\
\hline
\end{tabular}

Tablo 4'teki Cronbach Alfa değerleri incelendiğinde turizmin etkileri ölçeğindeki boyutlardan çevresel etki boyutu 0,944 ile en yüksek güvenirliğe sahip boyut olmuştur. Sosyal ekonomik etki $(0,864)$ ve sosyo-kültürel etki $(0,744)$ boyutlarının güvenilir olduğu görülmektedir. Turizmin etkileri ölçeği $(0,902)$ geneline bakıldığında ölçeğin oldukça güvenir olduğu görülmektedir. Cittaslow imajı ölçeğinin $(0,898)$ ise yüksek düzeyde güvenilirlik sağladığ 1 söylenebilir.

\subsection{Hipotez Testlerine Yönelik Bulgular}

Katılımcıların ikamet ettikleri yere göre turizm etkileri ve Cittaslow imajı alg1 düzeylerinin farklılık gösterip göstermediğini tespit etmek amacıyla bağımsız örneklem $t$ testi yapılışı ve sonuçlar Tablo 5 'te verilmiştir. $T$ testi iki grup arasındaki ortalama karşılaştırması da kullanılmaktadır. Varyansların eşit dağılım şartı sağlanmasa bile $t$ testi sonuçlarının yorumlanması varyansların eşit dağılıp dağılmadığına göre yapılmaktadır.

Yapılan Levene testi sonucunda sosyo-ekonomik etki ve çevresel etki boyutlarının homojen dağılmadığı, sosyo-kültürel etki boyutunun ise homojen dağıldığ 1 görülmektedir. Tablo 5 'teki $\mathrm{t}$ testi sonuçlarına göre sosyo-ekonomik etki boyutunun ikamet edilen yere göre farklılık göstermediği $(p>0,05)$ tespit edilmiştir. Buna göre $\mathbf{H}_{1 a}$ reddedilmiştir. Çevresel etki ve sosyo kültürel etki boyutlarının ortalamalarında ise ikamet edilen yer açısından Seferihisar lehine anlamlı farklılık $(\mathbf{p}<0,05)$ tespit edilmiştir. Buna göre $\mathbf{H}_{\mathbf{1 b}}$ ve $\mathbf{H}_{1 \mathbf{c}}$ kabul edilmiştir.

Tablo 5. İkamet Yerine Göre Turizmin Etkileri ve Cittaslow İmajı t Testi Sonuçları

\begin{tabular}{|c|c|c|c|c|c|c|c|c|}
\hline \multirow[b]{2}{*}{ Boyutlar } & \multirow[b]{2}{*}{ Yer } & \multirow[b]{2}{*}{$\mathbf{n}$} & \multirow[b]{2}{*}{$\bar{x}$} & \multirow[b]{2}{*}{ s.s. } & \multicolumn{2}{|c|}{ Levene Testi } & \multicolumn{2}{|c|}{ t Testi } \\
\hline & & & & & $\mathbf{F}$ & $\mathbf{P}$ & $\mathbf{T}$ & $\begin{array}{l}\text { p (iki } \\
\text { uçlu) }\end{array}$ \\
\hline \multirow{2}{*}{$\begin{array}{c}\text { Sosyo- } \\
\text { Ekonomik Etki }\end{array}$} & Gökçeada & 251 & 3,96 & 0,59 & \multirow{2}{*}{12,031} & \multirow{2}{*}{,001 } & \multirow{2}{*}{1,639} & \multirow{2}{*}{ 102 } \\
\hline & Seferihisar & 203 & 3,86 & 0,76 & & & & \\
\hline \multirow{2}{*}{ Çevresel Etki } & Gökçeada & 251 & 2,26 & 0,80 & \multirow{2}{*}{36,215} & \multirow{2}{*}{,000 } & \multirow{2}{*}{$-7,628$} & \multirow{2}{*}{,000 } \\
\hline & Seferihisar & 203 & 2,95 & 1,06 & & & & \\
\hline \multirow{2}{*}{$\begin{array}{c}\text { Sosyo-Külttürel } \\
\text { Etki }\end{array}$} & Gökçeada & 251 & 3,05 & 0,60 & \multirow{2}{*}{0,750} & \multirow{2}{*}{,387 } & \multirow{2}{*}{$-5,115$} & \multirow{2}{*}{,000 } \\
\hline & Seferihisar & 203 & 3,35 & 0,64 & & & & \\
\hline \multirow{2}{*}{$\begin{array}{c}\text { CITTASLOW } \\
\text { IMAJI }\end{array}$} & Gökçeada & 251 & 4,35 & 0,72 & \multirow{2}{*}{4,758} & \multirow{2}{*}{,030 } & \multirow{2}{*}{0,629} & \multirow{2}{*}{,530 } \\
\hline & Seferihisar & 203 & 4,30 & 0,85 & & & & \\
\hline
\end{tabular}


İmaj ölçeğine yönelik yapılan Levene testine göre varyansların homojen dağılmadığı görülmektedir. Bağımsız örneklem $t$ testi sonucuna göre Gökçeada ve Seferihisar arasında anlamlı bir farklılık $(p>0,05)$ tespit edilememiştir. Buna göre $\mathbf{H}_{2}$ reddedilmiştir.

Cinsiyet açısından turizmin etkileri ölçeğinin boyutlarının anlamlı gösterip göstermediğine yönelik yapılan bağımsız örneklem $t$ testi sonuçları verilmiştir (Tablo 6). Levene testine göre çevresel etki boyutunun varyansının homojen dağılmadığı ancak sosyo-ekonomik etki boyutunun ve sosyo-kültürel etki boyutlarının varyanslarının homojen dağıldığı görülmektedir. $T$ testi sonuçlarına göre turizmin etkileri boyutları arasında cinsiyet açısından istatistiki açıdan anlamlı $(p>0,05)$ bir farklılık tespit edilememiştir. Buna göre $\mathbf{H}_{3 \mathbf{a}}, \mathbf{H}_{3 \mathbf{b}}$ ve $\mathbf{H}_{3 \mathbf{c}}$ reddedilmiştir.

Tablo 6. Cinsiyete Göre Turizmin Etkileri ve Cittaslow İmajı t Testi Sonuçları

\begin{tabular}{|c|c|c|c|c|c|c|c|c|}
\hline \multirow[b]{2}{*}{ Boyutlar } & \multirow[b]{2}{*}{ Cinsiyet } & \multirow[b]{2}{*}{$\mathbf{n}$} & \multirow[b]{2}{*}{$\bar{x}$} & \multirow[b]{2}{*}{ s.s. } & \multicolumn{2}{|c|}{ Levene Testi } & \multicolumn{2}{|c|}{ t Testi } \\
\hline & & & & & F & $\mathbf{P}$ & $\mathrm{T}$ & $\begin{array}{l}\text { p (iki } \\
\text { uçlu) }\end{array}$ \\
\hline \multirow{2}{*}{$\begin{array}{c}\text { Sosyo- } \\
\text { Ekonomik Etki }\end{array}$} & Kadın & 256 & 3,95 & 0,66 & \multirow{2}{*}{1,438} & \multirow{2}{*}{,231 } & \multirow{2}{*}{1,344} & \multirow{2}{*}{, 179 } \\
\hline & Erkek & 198 & 3,87 & 0,69 & & & & \\
\hline \multirow{2}{*}{ Çevresel Etki } & Kadın & 256 & 2,54 & 0,94 & \multirow{2}{*}{5,181} & \multirow{2}{*}{, 023} & \multirow{2}{*}{$-0,587$} & \multirow{2}{*}{, 558} \\
\hline & Erkek & 198 & 2,60 & 1,05 & & & & \\
\hline \multirow{2}{*}{$\begin{array}{c}\text { Sosyo-Kültürel } \\
\text { Etki }\end{array}$} & Kadın & 256 & 3,20 & 0,64 & \multirow[b]{2}{*}{0,094} & \multirow[b]{2}{*}{,760 } & \multirow[b]{2}{*}{0,623} & \multirow{2}{*}{,533 } \\
\hline & Erkek & 198 & 3,17 & 0,63 & & & & \\
\hline \multirow{2}{*}{$\begin{array}{c}\text { CITTASLOW } \\
\text { IMAJI }\end{array}$} & Kadın & 256 & 4,32 & 0,78 & \multirow{2}{*}{0,204} & \multirow{2}{*}{,652 } & \multirow{2}{*}{$-0,447$} & \multirow{2}{*}{,655 } \\
\hline & Erkek & 198 & 4,35 & 0,79 & & & & \\
\hline
\end{tabular}

Cinsiyet açısından Cittaslow imajına yönelik olarak yapılan levene testi sonuçlarına göre varyansların homojen dağılmadığı gözlenmektedir. T testi sonucunda Kadın ve erkek katılımcılar arasında Cittaslow imajı açısından istatistiki bir farklılık bulunmamıştır (Tablo 6). Buna göre $\mathbf{H}_{4}$ reddedilmiştir.

Turizmin etkileri ölçeği boyutlarının medeni durum açısından farklılık gösterip göstermediğini yönelik yapılan $\mathrm{t}$ testi sonuçları Tablo 7 'de verilmiştir. Levene testi sonuçlarına göre çevresel etki boyutu homojen dağılırken sosyo-ekonomik etki ve sosyo-kültürel etki boyutları homojen dağılmıştır. $T$ testi sonuçlarına göre sosyo ekonomik etki boyutunun medeni durum açısından istatistiki bir fark göstermediği $(p>0,05)$ tespit edilmiştir. Buna göre $\mathbf{H}_{5 a}$ reddedilmiştir. Çevresel etki ve sosyo-kültürel etki boyutlarında medeni durum açısından bekâr katılımcılar lehine anlamlı farklılık $(p<0,05)$ gösterdiği tespit edilmiştir. Buna göre $\mathbf{H}_{\mathbf{5 b}}$ ve $\mathbf{H}_{\mathbf{s}}$ kabul edilmiştir. 
Tablo 7. Medeni Duruma Göre Turizmin Etkileri ve Cittaslow İmajı t Testi Sonuçları

\begin{tabular}{|c|c|c|c|c|c|c|c|c|}
\hline \multirow[b]{2}{*}{ Ölçek } & \multirow[b]{2}{*}{$\begin{array}{l}\text { Medeni } \\
\text { Durum }\end{array}$} & \multirow[b]{2}{*}{$\mathbf{n}$} & \multirow[b]{2}{*}{$\bar{x}$} & \multirow[b]{2}{*}{ s.s. } & \multicolumn{2}{|c|}{ Levene Testi } & \multicolumn{2}{|c|}{ t Testi } \\
\hline & & & & & $\mathbf{F}$ & $\mathbf{P}$ & $\mathbf{T}$ & $\begin{array}{l}\text { p (iki } \\
\text { uçlu) }\end{array}$ \\
\hline \multirow{2}{*}{$\begin{array}{c}\text { Sosyo- } \\
\text { Ekonomik Etki }\end{array}$} & Evli & 225 & 3,93 & 0,66 & \multirow{2}{*}{0,162} & \multirow{2}{*}{,687 } & \multirow{2}{*}{0,476} & \multirow{2}{*}{ 634 } \\
\hline & Bekâr & 229 & 3,90 & 0,68 & & & & \\
\hline \multirow{2}{*}{ Çevresel Etki } & Evli & 225 & 2,37 & 0,90 & \multirow{2}{*}{8,708} & \multirow{2}{*}{,003 } & \multirow{2}{*}{$-4,339$} & \multirow{2}{*}{,000 } \\
\hline & Bekâr & 229 & 2,76 & 1,03 & & & & \\
\hline \multirow{2}{*}{$\begin{array}{c}\text { Sosyo-Kültürel } \\
\text { Etki }\end{array}$} & Evli & 225 & 3,01 & 0,62 & \multirow{2}{*}{0,595} & \multirow{2}{*}{,441 } & \multirow{2}{*}{$-6,255$} & \multirow{2}{*}{,000 } \\
\hline & Bekâr & 229 & 3,36 & 0,59 & & & & \\
\hline \multirow{2}{*}{$\begin{array}{c}\text { CITTASLOW } \\
\text { IMAJI }\end{array}$} & Evli & 225 & 4,26 & 0,78 & \multirow{2}{*}{0,012} & \multirow{2}{*}{,913 } & \multirow{2}{*}{$-1,832$} & \multirow{2}{*}{,068 } \\
\hline & Bekâr & 229 & 4,40 & 0,77 & & & & \\
\hline
\end{tabular}

Medeni durum açısından Cittaslow imajı ölçeğine yönelik yapılan Levene testine göre varyansların homojen dağıldığı görülmektedir (Tablo 7). Bağımsız örneklem $t$ testi sonucuna göre evli ve bekâr katılımcılar arasında anlamlı bir farklılık $(p>0,05)$ tespit edilememiştir. Buna göre $\mathbf{H}_{6}$ reddedilmiştir.

Yaş değişkenine göre turizmin etkilerinin farklılık gösterip göstermediğini yönelik yapılan tek yönlü varyans analizi sonuçları Tablo 8' de verilmektedir. Öncelikle boyutlardaki değişkenlerin varyans homojenliği kontrol edilmiştir. Buna göre çevresel etki boyutunda varyanslar homojen dağılmazken sosyo-ekonomik ve sosyo-kültürel etki boyutlarında varyanslar homojen dağılmıştır. Yapılan tek yönlü varyans analizi sonucuna göre bütün boyutların yaş değişkeni açısından anlamlı farklılık $(p<0,05)$ gösterdiği tespit edilmiştir. Farkın kaynağının öğrenilmesi amacıyla post-hoc testleri uygulanmiştır. Sosyo-ekonomik etki boyutunda uygulanan Tukey testi sonucuna göre 25-34 yaş grubundaki katılımcıların 18-24 yaş grubundaki ve 55 yaş ve üstü katılımcılara göre sosyo-ekonomik etkilerini daha olumlu değerlendirdikleri görülmektedir. Buna göre $\mathbf{H}_{7 a}$ kabul edilmiştir.

Çevresel etki boyutunda uygulanan Dunnett's-C testi sonucuna göre 18-24 yaş grubundaki katılımcıların diğer katılımcılara göre turizmin çevresel etkilerini daha olumlu değerlendirdikleri görülmektedir. Sosyo-kültürel etki boyutunda uygulanan Tukey testi sonucunda 18-24 yaş grubundaki katılımcıların 25-34 yaş grubundaki katılımcılara göre daha olumlu değerlendirdikleri ve 25-34 yaş grubundaki katılımcıların diğer üç gruplardaki katılımcılara göre turizmin sosyo-kültürel etkilerini daha olumlu değerlendirdikleri görülmektedir. Buna göre $\mathbf{H}_{7 \mathrm{~b}}$ ve $\mathbf{H}_{7 \mathrm{c}}$ kabul edilmiştir.

Yaş değişkeni açısından Cittaslow imajı düzeyinin anlamlı bir farklılık gösterip göstermediğini tespit etmek amacıyla tek yönlü varyans analizi yapılmıştır (Tablo 8). Analiz sonucunda gruplar arasında anlamlı bir farklılık $(p<0,05)$ tespit edilmiştir. Grupların varyanslarının homejen dağıldığ 1 tespit edildiğinden uygulanan Tukey testi ile farkın kaynağı araştırılmıştır. Buna göre 18-25, 25-34 ve 35-44 yaş grupları ile 45-54 ve 55 ve üstü yaş grupları arasında 18-24, 25-34 ve 35-44 yaş grupları lehine anlamlı farklılık bulunmuştur. Buna göre $\mathbf{H}_{8}$ kabul edilmiştir. 
Tablo 8. Yaşa Göre Turizm Etkileri ve Cittaslow İmajı Anova Sonuçları

\begin{tabular}{|c|c|c|c|c|c|c|c|c|}
\hline Ölçek & & Yaş & $\mathbf{n}$ & $\overline{\mathrm{x}}$ & s.s. & $\mathbf{F}$ & $\mathbf{P}$ & $\begin{array}{c}\text { Farkın } \\
\text { Kaynağ1 }\end{array}$ \\
\hline \multirow{5}{*}{$\begin{array}{c}\text { Sosyo- } \\
\text { Ekonomik } \\
\text { Etki }\end{array}$} & 1 & 18-24 Yaş & 116 & 3,81 & 0,679 & \multirow{5}{*}{3,237} & \multirow{5}{*}{0,012} & \multirow{5}{*}{$2>1-5$} \\
\hline & 2 & 25-34 Yaş & 173 & 4,02 & 0,631 & & & \\
\hline & 3 & 35-44 Yaş & 88 & 3,97 & 0,624 & & & \\
\hline & 4 & 45-54 Yaş & 47 & 3,82 & 0,757 & & & \\
\hline & 5 & $\begin{array}{l}55 \text { Yaş ve } \\
\text { üstü }\end{array}$ & 30 & 3,67 & 0,773 & & & \\
\hline \multirow{5}{*}{ Çevresel Etki } & 1 & 18-24 Yaş & 116 & 2,91 & 1,049 & \multirow{5}{*}{5,304} & \multirow{5}{*}{$0,000^{*}$} & \multirow{5}{*}{$1>2-3-4-5$} \\
\hline & 2 & 25-34 Yaş & 173 & 2,42 & 0,928 & & & \\
\hline & 3 & 35-44 Yaş & 88 & 2,45 & 0,907 & & & \\
\hline & 4 & 45-54 Yaş & 47 & 2,58 & 1,033 & & & \\
\hline & 5 & $\begin{array}{l}55 \text { Yaş ve } \\
\text { üstü }\end{array}$ & 30 & 2,40 & 0,928 & & & \\
\hline \multirow{5}{*}{$\begin{array}{c}\text { Sosyo- } \\
\text { Kültürel Etki }\end{array}$} & 1 & 18-24 Yaş & 116 & 3,37 & 0,591 & \multirow{5}{*}{6,208} & \multirow{5}{*}{0,000} & \multirow{5}{*}{$1>2>3-4-5$} \\
\hline & 2 & 25-34 Yaş & 173 & 3,22 & 0,598 & & & \\
\hline & 3 & 35-44 Yaş & 88 & 3,07 & 0,680 & & & \\
\hline & 4 & 45-54 Yaş & 47 & 3,04 & 0,655 & & & \\
\hline & 5 & $\begin{array}{l}55 \text { Yaş ve } \\
\text { üstü }\end{array}$ & 30 & 2,85 & 0,628 & & & \\
\hline \multirow{5}{*}{$\begin{array}{l}\text { CITTASLOW } \\
\text { IMAJI }\end{array}$} & 1 & 18-24 Yaş & 116 & 4,38 & 0,782 & \multirow{5}{*}{5,029} & \multirow{5}{*}{0,001} & \multirow{5}{*}{$1-2-3>4-5$} \\
\hline & 2 & 25-34 Yaş & 173 & 4,41 & 0,739 & & & \\
\hline & 3 & 35-44 Yaş & 88 & 4,38 & 0,740 & & & \\
\hline & 4 & 45-54 Yaş & 47 & 4,13 & 0,755 & & & \\
\hline & 5 & $\begin{array}{l}55 \text { Yaş ve } \\
\text { üstü }\end{array}$ & 30 & 3,81 & 0,962 & & & \\
\hline
\end{tabular}

Meslek değişkenine göre turizmin etkilerinin farklılık gösterip göstermediğini yönelik yapılan tek yönlü varyans analizi sonuçları Tablo 9'da görülmektedir. Yapılan analiz sonucunda turizmin etkileri boyutlarından yalnızca çevresel etki boyunda anlamlı farklılık $(p<0,05)$ bulunmuştur. Yapılan homojenlik testine göre çevresel etki boyutundaki gruplar arası varyansın homojen dağılmadığı tespit edilmiştir. Farkın kaynağının tespiti için yapılan Dunnett's-C testi sonucunda kamu çalışanlarının esnaf ve özel sektör çalışanlarına göre turizmin çevresel etkilerini daha olumlu değerlendirdikleri bulunmuştur. Esnaf, kamu çalışanı ve özel sektör çalışanı katılımcıların ise ev hanımı ve emekli katılımcılardan çevresel etkileri daha olumlu değerlendirdikleri görülmektedir. Buna göre $\mathbf{H}_{9_{a}}$ ve $\mathbf{H}_{9_{c}}$ reddedilirken $\mathbf{H}_{9 b}$ kabul edilmiştir.

Cittaslow imajı düzeyinin meslek değişkeni açısından anlamlı bir farklılık gösterip göstermediğini tespit etmek amacıyla tek yönlü varyans analizi yapılmıştır. Analiz sonucunda gruplar arasında anlamlı bir farklılık $(p>0,05)$ tespit edilmemiştir. Buna göre $\mathbf{H}_{10}$ reddedilmiştir. 
Tablo 9. Mesleğe Göre Turizm Etkileri ve Cittaslow İmajı Anova Sonuçları

\begin{tabular}{|c|c|c|c|c|c|c|c|c|}
\hline Ölçek & \multicolumn{2}{|r|}{ Meslek } & $\mathbf{n}$ & $\bar{x}$ & s.s. & $\mathbf{F}$ & $\mathrm{p}$ & Farkın \\
\hline \multirow{6}{*}{$\begin{array}{c}\text { Sosyo- } \\
\text { Ekonomik } \\
\text { Etki }\end{array}$} & 1 & Esnaf & 139 & 3,87 & 0,698 & \multirow{6}{*}{2,115} & \multirow{6}{*}{0,063} & \multirow{6}{*}{-} \\
\hline & 2 & Kamu Çalışanı & 49 & 3,82 & 0,752 & & & \\
\hline & 3 & $\begin{array}{l}\text { Özel Sektör } \\
\text { Çalışanı }\end{array}$ & 129 & 3,85 & 0,609 & & & \\
\hline & 4 & Ev Hanımı & 30 & 4,17 & 0,399 & & & \\
\hline & 5 & Emekli & 31 & 4,06 & 0,490 & & & \\
\hline & 6 & Öğrenci & 76 & 4,02 & 0,787 & & & \\
\hline \multirow{6}{*}{ Çevresel Etki } & 1 & Esnaf & 139 & 2,53 & 0,990 & \multirow{6}{*}{8,199} & \multirow{6}{*}{$0,000^{*}$} & \multirow{6}{*}{$2>1-3>4-5$} \\
\hline & 2 & Kamu Çalışanı & 49 & 3,28 & 1,046 & & & \\
\hline & 3 & $\begin{array}{l}\text { Özel Sektör } \\
\text { Çalışanı }\end{array}$ & 129 & 2,58 & 1,101 & & & \\
\hline & 4 & Ev Hanımı & 30 & 2,09 & 0,650 & & & \\
\hline & 5 & Emekli & 31 & 2,21 & 0,665 & & & \\
\hline & 6 & Öğrenci & 76 & 2,47 & 0,683 & & & \\
\hline \multirow{6}{*}{$\begin{array}{c}\text { Sosyo- } \\
\text { Kültürel Etki }\end{array}$} & 1 & Esnaf & 139 & 3,19 & 0,726 & \multirow{6}{*}{2,225} & \multirow{6}{*}{0,051} & \multirow{6}{*}{-} \\
\hline & 2 & Kamu Çalışanı & 49 & 3,44 & 0,583 & & & \\
\hline & 3 & $\begin{array}{l}\text { Özel Sektör } \\
\text { Çalışanı }\end{array}$ & 129 & 3,15 & 0,622 & & & \\
\hline & 4 & Ev Hanımı & 30 & 3,00 & 0,548 & & & \\
\hline & 5 & Emekli & 31 & 3,15 & 0,524 & & & \\
\hline & 6 & Öğrenci & 76 & 3,17 & 0,549 & & & \\
\hline \multirow{6}{*}{$\begin{array}{c}\text { CITTASLOW } \\
\text { IMAJI }\end{array}$} & 1 & Esnaf & 139 & 4,35 & 0,743 & \multirow{6}{*}{1,504} & \multirow{6}{*}{0,187} & \multirow{6}{*}{ - } \\
\hline & 2 & Kamu Çalışanı & 49 & 4,21 & 0,828 & & & \\
\hline & 3 & $\begin{array}{l}\text { Özel Sektör } \\
\text { Çalışanı }\end{array}$ & 129 & 4,24 & 0,786 & & & \\
\hline & 4 & Ev Hanımı & 30 & 4,59 & 0,665 & & & \\
\hline & 5 & Emekli & 31 & 4,33 & 0,746 & & & \\
\hline & 6 & Öğrenci & 76 & 4,42 & 0,852 & & & \\
\hline
\end{tabular}

Turizmin etkileri boyutlarının gelir kaynağı değişkeni açısından farklılık gösterip göstermediğine yönelik yapılan tek yönlü varyans analizi yapılmıştır (Tablo 10). Yapılan analiz sonucunda turizmin etkileri boyutlarından sosyo-ekonomik etki boyutunda anlamlı bir farklılık $(p>0,05)$ bulunmamıştır. Buna göre $\mathbf{H}_{11 a}$ reddedilmiştir.

Çevresel etki ve sosyo-kültürel etki boyutlarında anlamlı farklılık $(\mathrm{p}<0,05)$ tespit edilmiştir. Homojenlik testi sonuçlarına göre çevresel etki ve sosyo-kültürel etki boyutlarında gruplar arası varyansların homojen dağılmadığı tespit edilmiştir. Farkın kaynağının tespiti için yapılan Dunnett's-C testi sonucunda her iki boyutta gelirlerinin bir kısmını veya tamamını turizmden elde eden katılımcılar ile gelirlerini turizm dışı sektörlerden elde eden katılımcılar arasında turizmden gelir elde edenler lehine anlamlı bir farklılık tespit edilmiştir. Buna göre $\mathbf{H}_{11 b}$ ve $\mathbf{H}_{11 \mathrm{c}}$ kabul edilmiştir. 
Cittaslow imajı düzeyinin gelir kaynağı değişkeni açısından anlamlı bir farklılık gösterip göstermediğini tespit etmek amacıyla tek yönlü varyans analizi yapılmıştır (Tablo 10). Analiz sonucunda gruplar arasında anlamlı bir farklılık $(p>0,05)$ tespit edilmemiştir. Buna göre $\mathbf{H}_{12}$ reddedilmiştir.

Tablo 10. Gelirin Kaynağına Göre Turizm Etkileri ve Cittaslow İmajı Anova Sonuçları

\begin{tabular}{|c|c|c|c|c|c|c|c|c|}
\hline Ölçek & & Gelirin Kaynağı & $\mathbf{n}$ & $\bar{x}$ & s.s. & $\mathbf{F}$ & $\mathbf{P}$ & $\begin{array}{c}\text { Farkın } \\
\text { Kaynağ1 }\end{array}$ \\
\hline \multirow{3}{*}{$\begin{array}{c}\text { Sosyo- } \\
\text { Ekonomik } \\
\text { Etki }\end{array}$} & 1 & Turizmle İlgili & 72 & 3,92 & 0,694 & \multirow{3}{*}{0,419} & \multirow{3}{*}{0,658} & \multirow{3}{*}{-} \\
\hline & 2 & Turizmle İlgili Değil & 348 & 3,92 & 0,661 & & & \\
\hline & 3 & $\begin{array}{l}\text { Gelirimin Bir K1smı } \\
\text { Turizmden }\end{array}$ & 34 & 3,81 & 0,754 & & & \\
\hline \multirow{3}{*}{ Çevresel Etki } & 1 & Turizmle İlgili & 72 & 3,05 & 1,267 & \multirow{3}{*}{23,461} & \multirow{3}{*}{$0,000^{*}$} & \multirow{3}{*}{$1-3>2$} \\
\hline & 2 & Turizmle İlgili Değil & 348 & 2,40 & 0,826 & & & \\
\hline & 3 & $\begin{array}{l}\text { Gelirimin Bir K1smı } \\
\text { Turizmden }\end{array}$ & 34 & 3,23 & 1,204 & & & \\
\hline \multirow{3}{*}{$\begin{array}{l}\text { Sosyo- } \\
\text { Külttürel Etki }\end{array}$} & 1 & Turizmle İlgili & 72 & 3,37 & 0,788 & \multirow{3}{*}{11,480} & \multirow{3}{*}{$0,000 *$} & \multirow{3}{*}{$1-3>2$} \\
\hline & 2 & Turizmle İlgili Değil & 348 & 3,11 & 0,579 & & & \\
\hline & 3 & $\begin{array}{l}\text { Gelirimin Bir Kısmı } \\
\text { Turizmden }\end{array}$ & 34 & 3,55 & 0,633 & & & \\
\hline \multirow{3}{*}{$\begin{array}{l}\text { CITTASLOW } \\
\text { IMAJI }\end{array}$} & 1 & Turizmle İlgili & 72 & 4,38 & 0,677 & \multirow{3}{*}{0,677} & \multirow{3}{*}{0,509} & \multirow{3}{*}{-} \\
\hline & 2 & Turizmle İlgili Değil & 348 & 4,33 & 0,814 & & & \\
\hline & 3 & $\begin{array}{l}\text { Gelirimin Bir K1smı } \\
\text { Turizmden }\end{array}$ & 34 & 4,19 & 0,637 & & & \\
\hline
\end{tabular}

Turizmin etkileri boyutları, Cittaslow imajı ölçeği, katılımcıların yaşı ve bölgede yaşam süreleri arasındaki ilişkinin tespit edilmesi için korelasyon analizi yapılmıştır. Korelasyon analizi değişkenler arasındaki ilişkinin yönünü ve şiddetini gösteren bir analiz tekniğidir. Korelasyon katsayısı 0 ile 1 arasında değer alır ve değer 1'e yaklaştıkça ilişkinin şiddeti kuvvetlenir. Katsayının işareti ilişkinin yönünü göstermektedir. Tablo 11'e göre Çevresel etki ile sosyo-kültürel etki (r=0,641), Cittaslow imajı ile Sosyo-ekonomik etki $(r=0,627)$ arasında orta şiddette ve pozitif yönlü ilişkiler tespit edilmiştir. Cittaslow imajı ile yaş $(r=-0,192)$, bölgede yaşam süresi $(r=-0,132)$ ve çevresel etki $(\mathrm{r}=-0,111)$ arasında düşük şiddette ve negatif yönlü ilişkiler tespit edilmiştir. Cittaslow imajı ile sosyo-kültürel etki arasında anlamlı bir ilişki $(p>0,05)$ bulunamamıştır. Buna göre $\mathbf{H}_{13 c}$ reddedilmiştir. 
Tablo 11. Cittaslow İmajı ile Diğer Değişkenler Arasında Korelasyon Analizi Sonuçları

\begin{tabular}{|c|c|c|c|c|c|c|}
\hline & 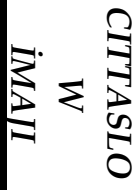 & 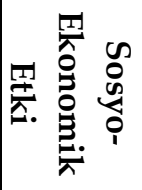 & 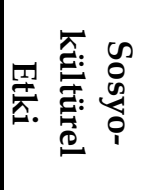 & 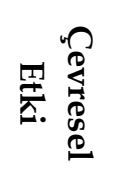 & $\underset{\text { 虫 }}{\infty}$ & 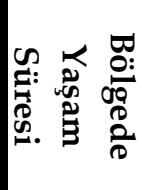 \\
\hline $\begin{array}{c}\text { CITTASLOW } \\
\text { IMAJI }\end{array}$ & 1 & $627^{* *}$ &,- 004 &,$- 111^{*}$ &,$- 192^{* *}$ &,$- 132^{* *}$ \\
\hline $\begin{array}{l}\text { Sosyo-ekonomik } \\
\text { Etki }\end{array}$ &, $627^{* *}$ & 1 &,$- 099^{*}$ &,$- 210^{* *}$ &,- 061 &,- 058 \\
\hline $\begin{array}{l}\text { Sosyo-kültürel } \\
\text { Etki }\end{array}$ &,- 004 &,$- 099^{*}$ & 1 & $641^{* *}$ &,$- 246^{* *}$ &,- 019 \\
\hline Çevresel Etki &,$- 111^{*}$ &,$- 210^{* *}$ &, $641^{* *}$ & 1 &,$- 123^{* *}$ &,- 028 \\
\hline Yaş &,$- 192^{* *}$ &,- 061 &,$- 246^{* *}$ &,$- 123^{* *}$ & 1 & $285^{* *}$ \\
\hline $\begin{array}{l}\text { Bölgede Yaşam } \\
\text { Süresi }\end{array}$ &,$- 132^{* *}$ &,- 058 &,- 019 &,- 028 &, $285^{* *}$ & 1 \\
\hline
\end{tabular}

Cittaslow imajı ile sosyo-ekonomik etki, çevresel etki, yaş ve bölgede yaşam süresi arasındaki ilişki korelasyon analizi ile tespit edildikten sonra değişkenlerin Cittaslow imajını açılama düzeylerini bulmak için regresyon analizi yapılmıştır (Tablo 12).

Tablo 12. Cittaslow İmajına Yönelik Regresyon Analizi Sonuçları

\begin{tabular}{|c|c|c|c|c|}
\hline Model (1) & $\beta$ & $\begin{array}{c}\text { Standart } \\
\text { Hata }\end{array}$ & $\begin{array}{c}t \\
\text { Değeri }\end{array}$ & Önem Düzeyi \\
\hline Sabit & 1,899 & 0,199 & 9,559 & , 000 \\
\hline Sosyo-Ekonomik Etki & 0,717 & 0,043 & 16,641 & ,000 \\
\hline Çevresel Etki & $\begin{array}{c}- \\
0,001\end{array}$ & 0,030 & $-0,046$ & ,964 \\
\hline Yaş & $\begin{array}{c}- \\
0,010\end{array}$ & 0,003 & $-3,662$ & ,000 \\
\hline Bölgede Yaşam Süresi & $\begin{array}{c}- \\
0,005\end{array}$ & 0,003 & $-1,506$ & 133 \\
\hline
\end{tabular}

Bağımsız değişkenler ile Cittaslow imajına ilişkin kurulan regresyon modeli $\mathrm{F}=81,206$ ve $\mathrm{p}<0,05$ olduğundan istatistiki olarak anlamlıdır. Buna göre modeldeki bağımsız değişkenlerin bağımlı değişkenleri açıklama oranı \%42,1'dir.

Modeldeki katsayılar incelendiğinde çevresel etkinin ve bölgede yaşam süresinin $(p>0,05)$ Cittaslow imajı üzerinde etkisi tespit edilememiştir. Buna göre $\mathbf{H}_{13 \mathbf{b}}$ ve $\mathbf{H}_{15}$ reddedilmiştir. Sosyo-ekonomik etki $(\beta=0,717 ; p<0,05)$ ve yaş $(\beta=0,01 ; p<0,05)$ değişkenlerinin Cittaslow imajı üzerinde etkili olduğu görülmektedir. Buna göre $\mathbf{H}_{13 a}$ ve $\mathbf{H}_{14}$ kabul edilmiştir. 


\section{Sonuç ve Değerlendirme}

Cittaslow etiketi bulunan kentler, önemli bir marka değeri bulundurmaktadır. Dünyadaki turizm yönelim türleri artmakta; turizm, sadece kitle turizmine bağlı olarak gelişim göstermemektedir. Kentleri ve yaşantıları hızla devam eden, kalabalık, gürültülü yaşam alanını standart hale getirmeye çalışan ve bunun gerçekten gerekli olduğuna inanan, küresel yönelimler, Cittaslow ile sakin yaşanabileceği düşüncesini ortaya çıkarmıştır. Yavaş akımının faydalarından birisi Cittaslow'un oluşum göstermesiyle turizm alanında pozitif değişiklerin görülmesidir. İtalya'da meydana gelen hareket, Türkiye'de on yedi ilçe-belde seviyesindeki şehri kendisine dâhil etmiştir. Bunlardan birincisi olan Seferihisar, Türkiye'deki ilk Cittaslow olarak turizm konusunda önemli faydalar sağlamıştır.

Araştırmaya yönelik sonuçlar değerlendirildiğinde $\mathbf{H}_{\mathbf{1 b}}$ ve $\mathbf{H}_{1 \mathrm{c}}$ hipotezleri desteklenirken; $\mathbf{H}_{1 a}$ hipotezi desteklenmemiştir. Bu bulgulara göre her iki Cittaslow şehrin sakinlerinin turizmin sosyo-ekonomik etkilerini ayn düzeyde olumlu algıladıkları söylenebilir. Gökçeada'da turizmin negatif çevresel etkilerinin yerel halk tarafından daha çok hissedildiği görülmektedir. Sosyo-kültürel boyut açısından değerlendirildiğinde Seferihisar halkının turizmin kültürel değerlerin korunmasında olumlu etkilerinin daha yüksek düzeyde algilandiğ 1 söylenebilir. $\mathbf{H}_{2}$ hipotezi desteklenmemiştir. Bu sonuç Cittaslow imajına yönelik cevapların ortalamasının her iki şehir içinde yüksek düzeyde gerçekleştiği görülmektedir. Buradan iki Cittaslow şehrindeki yerel halkın da Cittaslow markasına olumlu baktıkları ve Cittaslow şehri olmaktan memnun oldukları sonucuna varılabilir. $\mathbf{H}_{3 \mathbf{a}}, \mathbf{H}_{3 \mathbf{b}}, \mathbf{H}_{3 \mathbf{c}}$ ve $\mathbf{H}_{4}$ hipotezleri desteklenmemiştir. $\mathbf{H}_{5 \mathbf{b}}$ ve $\mathbf{H}_{5 \mathbf{c}}$ hipotezleri desteklenmiştir. $\mathrm{Bu}$ sonucu göre evli katılımcıların turizmin çevresel ve sosyo-kültürel etkilerini daha olumsuz değerlendirdikleri sonucuna ulaşılabilir. $\mathbf{H}_{5}$ ve $\mathbf{H}_{6}$ hipotezi desteklenmemiştir. $\mathbf{H}_{6}$ hipotezi sonucuna göre evli ve bekâr katılımcıların Cittaslow olmaktan aynı düzeyde memnun oldukları söylenebilir. $\mathbf{H}_{7 \mathbf{a}}, \mathbf{H}_{7 \mathrm{~b}}, \mathbf{H}_{7 \mathrm{c}}$ ve $\mathbf{H}_{8}$ hipotezleri desteklenmiştir. Analizden genç yaş gruplarının orta yaş ve üstü gruplara göre Cittaslow'a daha olumlu yaklaştıkları sonucuna varılabilir. $\mathbf{H}_{9 \mathbf{b}}, \mathbf{H}_{11 \mathbf{b}}, \mathbf{H}_{11 \mathrm{c}}, \mathbf{H}_{13 \mathbf{a}}$ ve $\mathbf{H}_{14}$ hipotezleri desteklenirken, $\mathbf{H}_{9 a}, \mathbf{H}_{9 c}, \mathbf{H}_{10}, \mathbf{H}_{11 a}, \mathbf{H}_{12}, \mathbf{H}_{13 b}, \mathbf{H}_{13 c}$ ve $\mathbf{H}_{15}$ hipotezleri desteklenmemiştir.

Araştırma kapsamında, Cittaslow sonrası Seferihisar'da önemli seviyede gelişmeler meydana gelmiştir. Seferihisar'ın söz konusu zaman aralığından önemli faydalar kazandığı, Cittaslow'un turizmin gelişim göstermesine belirli şekilde etkisi olduğu analiz edilmiştir. En önemli etkiler, bölgenin ulusal ve uluslararası seviyede tanınmasına katkı sağlanması şeklinde ifade edilmiştir. Bölgedeki turist miktarı, turizm yatırımları, iş ve istihdam imkânları yükselmiş, bölgedeki turizme yönelik yerel kültürel mirasın korunması ve bölgede çalışmaya olan istek arttırılmıştır. Bu alanda, turizm işletme işi yapanların ve otellerin, hem nitel bir şekilde gelişim göstermeleri ve hizmet kalitesini yükseltmeleri hem de Cittaslow sürecine yönetsel olarak fayda sağlamaları, destek vermeleri sinerjiyi yükseltecektir. Bunun yanı sıra, dünyada turizmin gelişim gösterdiği birçok destinasyonda gözlemlenmiş olan negatiflikler, bu bölgede tehlike oluşturmaya başlamıştır. Bir bölgenin tespit edilmesinden sonrası gözlenmiş olan arz, imar ve yapılaşma istekleri, büyük turizmin bölgeye akmış olması 
ve kıyı bölgelerinde betonlaşma tehlike durumunun, Seferihisar için risk meydana getirmeye başlamış olduğu görülmektedir. Bu sebeple özellikle yerel yönetimlerin bu konuda dikkat etmesi, imar ve yapılaşma konusu ile ilgili yasal düzenleme konusunda dikkatli olmaları gerekmektedir.

Araştırma sonucunda sosyo-ekonomik etki ve yaş değişkenlerinin Cittaslow imajı üzerinde etkili olduğu görülürken çevresel etkilerin ve bölgedeki yaşam süresinin Cittaslow imajı üzerinde bir etkisi olmadığı tespit edilmiştir. Yapılan araştırma sonucunda Gökçeada ve Seferihisar halklarının Cittaslow algıları arasında belirgin bir farklılık görülmemiştir. Her iki yöre halklarının da genel olarak Cittaslow'a olumlu baktıkları sonucuna ulaşılmıştır. Özellikle turizmden para kazanan genç kesim Cittaslow hakkında olumlu düşüncelere sahiptir. Turiste karşı negatif tutumlar henüz ortaya çıkmamıştır. Benzer şekilde Dündar ve Sert (2018) Seferihisar'ı ele aldıkları çalışmalarında yerel halkın Cittaslow'dan ve sosyo-ekonomik etkilerden memnun oldukları sonucuna ulaşarak bu çalışma ile benzer sonuçlar ortaya koymuşlardır.

Sonuç olarak Gökçeada'ya göre Seferihisar'da sosyo-kültürel ve çevresel etkilerin daha yüksek olduğu görülmektedir. Bu durum Seferihisar'ın Türkiye'deki ilk Cittaslow olması ile merkezleşmesi, Seferihisar'ın İzmir'e yakınlığı ve ulaşımının Gökçeada'ya göre çok daha kolay olması gibi nedenlerle açıklanabilir.

$\mathrm{Bu}$ çalışmaya benzer olarak yapılan çalışmalara yardımcı olması açısından aşağıdaki öneriler verilebilir:

- Her iki yöre halkının da genel olarak Cittaslow'un getirilerinden memnun oldukları söylenebilir. Belediyelerin bu konu hakkında halkı eğitme ve bilinçlendirme çalışmaları fayda sağlamıştır. Fakat bu alanda daha çok çalışma yapılmalı, üretime katılan halk bu alanda daha fazla aktif olmalıdır.

- Seferihisar ya da Gökçeada farklı ülkelerde bulunan farklı kültürel değerlere sahip sakin şehirler ile karşılaştırılarak farklar ve benzerlikler ortaya konulabilir.

- Seferihisar ve Gökçeada dışında yer alan sakin şehir hareketlerinin bulunduğu bölgeler birbirleri ile karşılaştırılarak eksiklikler giderilebilir.

- Gökçeada'nın ulaşım sorunu daha fazla gündeme getirilerek adaya seferler artırılabilir.

- Cittaslow bilincini arttırmayı amaçlayan belediyeler halk ve sivil toplum kuruluşları ile koordine şekilde hareket ederek daha fazla etkinlik düzenleyebilir.

\section{Kaynakça}

Andarabi, F. F., Altunöz, Ö., Hassan, A. (2014). Cittaslow Şehirlerde Yerel Halkın Turizme Yaklaşımı: Seferihisar Örneği, Eko-Gastronomi Dergisi, 1(1): 77-94.

Bucak, T., Turan, Ö. (2016). Bölge Turizmine Yeni Akımların Etkisi: Gökçeada Yavaş Yemek Örneği, Journal of Yasar University, 11(43): 211-219.

Butler, R. W. (1990). Alternative Tourism: Pious Hope or Trojan Horse?, Journal of Travel Research, 28(3): 40-45. 
Coşar, Y. (2014). Yavaş Şehir Olgusunun Kentsel Yaşam Kalitesi Üzerindeki Algılanan Etkisi, Anatolia: Turizm Araştırmaları Dergisi, 25(2): 226-240.

Çakıcı, A. C., Yenipınar, U., Benli, S. (2014). Yavaş Şehir Hareketi: Seferihisar Halkının Tutum ve Algıları İle Yaşam Doyumları, Seyahat ve Otel İşletmeciliği Dergisi, 11(3): 26-41.

Dündar, Y., Sert, A. N. (2018). Yerel Halkın Yavaş (Sakin) Şehir Hakkındaki Algıları: Seferihisar' da Nitel Bir Araştırma, Türk Turizm Araştırmaları Dergisi, 2(4): 74-91.

Gökaliler, E. (2017). Şehirlerin Markalaşması Sürecinde Marka Konumlandırmasının Rolü: Seferihisar Cittaslow Üzerine Bir İnceleme, Erciyes İletişim Dergisi, 5(1): 326-342.

Kazançoğlu, İ., Dirsehan, T. (2016). Sosyal İnovasyon İle Sakin Şehirlerarasındaki İlişkinin Sosyal Girişim(ci)ler Açısından İncelenmesi: Seferihisar Örneği, Ege Stratejik Araştırmalar Dergisi, 7(Özel Sayı): 135-161.

Mayer, H., Knox, P. L. (2009). Pace of Life and Quality of Life: A Slow City Charter 2: 21-40, (Eds) M. J. Sirgy et al., Community Quality of Life Indicators: Best Cases III, USA: Springer Science Business Media B.V.

Sarıbaş, Ö., Kömürcü, S., Güler, M. E. (2016). Yavaş Şehirlerde Yaşayan Z Kuşağının Çevre ve Sürdürülebilir Kalkınma Algıları: Seferihisar Örneği, Uluslararası Türk Dünyası Turizm Araştırmaları Dergisi, 1(2), 107-119.

Sezgin, M., Ünüvar, Ş. (2011). Sürdürülebilirlik ve Şehir Pazarlaması Ekseninde Yavaşşehir, Konya: Çizgi.

Yurtseven, H. R., Kaya, O., Harman, S. (2010). Yavaş Hareketi, Ankara: Detay Yayıncılık.

Cittaslow Türkiye, https://cittaslowturkiye.org (Erişim Tarihi: 28.06.2019).

Türkiye İstatistik Kurumu (TUIK) Adrese Dayalı Kayıt Sistemi 2018, https://www.nufusu.com (Erişim tarihi 05.04.2019) 